gamma-globulin and that, in liver disease, the antibody is frequently a macroglobulin, while in D.L.E. it is predominantly a 7S gamma-globulin (Weir and Holborow, 1962). Positive A.N.F. tests were found in the absence of a positive L.E. cell test confirming the findings of Calabresi and Greenberg (1960), Weir et al. (1961), and Gökcen (1962). Such results indicate abnormal immunological activity (Mackay and Gajdusek, 1958 ; Mackay and Wood, 1962). Unlike Calabresi and Greenberg's (1960) findings, antinuclear antibodies were not found in the sera from alcoholic subjects.

The abnormal proteins responsible for these serological findings might be a response to the liver damage or they may be an expression of the underlying, possibly genetic, abnormality of the reticulo-endothelial system. Relatives of patients with rheumatoid arthritis show significant increases in the positivity rate of the S.C.A.T. compared with relatives of healthy subjects (Ball and Lawrence, 1961), and healthy first-degree relatives of patients with agammaglobulinaemia also have an increased incidence of positive rheumatoid agglutination tests as well as frequent abnormalities of gamma-globulin (Fudenberg, German, and Kunkel, 1962). Their presence in certain types of liver disease points to an abnormality of the immunological apparatus. Serological studies on relatives of patients with chronic liver disease might be useful in revealing a genetically determined abnormality.

\section{Summary}

Serological studies for the presence of antinuclear antibodies, "rheumatoid" factors, and thyroglobulin antibodies were undertaken in 116 patients suffering from alcoholic, " juvenile," cryptogenic, or primary biliary cirrhosis or from virus hepatitis.

An increased incidence of positive latex and sheep-cell agglutination tests, compared with normals, was found in all the varieties of liver disease studied. The highest number of positive results were encountered in juvenile, cryptogenic, and primary biliary cirrhosis; in alcoholic cirrhosis and virus hepatitis the positivity rate was lower. The latex test was more often positive than the sheep-cell test.

Antinuclear antibodies were present in $42 \%$ of 38 sufferers from juvenile cirrhosis, and compared with normals their inci- dence was increased also in cryptogenic cirrhosis. They were not detected in patients with alcoholic cirrhosis and virus hepatitis.

The incidence of thyroglobulin antibodies did not differ from that found in normal subjects.

Our thanks are due to Professor D. N. Baron and Dr. W. J. D. Fleming for help with the investigation of the patients. The Irwin Strasburger Memorial Medical Foundation gave financial assistance.

\section{REPERENCES}

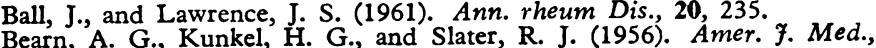
21,3 .

Bonomo, L., Lo Spalluto, J., and Ziff, M. (1963). Arth. and Rheum., 6, 104.

Calabresi, P., and Greenberg, M. (1960). F. clin. Invest., 39, 976

Dacie, J.' V.' (1956). Practical Haematology, 2nd ed. Churchill, London. Dresner, E., and Trombly, P. (1959). New Engl. ₹. Med., 261, 981.

Dresner, E., and Trombly, P. H. Müller-Eberhard, H. J., and Kunkel, H. G. (1957). ₹. exp. Med., 105, 425.

Franklin, M., Bean, W. B., Paul, W. D., Routh, J. I., de la Huerga, J., and Popper, H. (1951). f. clin. Invest., 30, 729.

Fudenberg, H., German, J. L., and Kunkel, H. G. (1962). Arth. and Rheum., 5, 565 .

Fulthorpe, A. J., Roitt, I. M., Doniach, D., and Couchman, K. (1961). f. clin. Path., 14, 654 .

Gökcen, M. (1962). ₹. Lab. clin. Med., 59, 533

Hijmans, W., Doniach, D., Roitt, I. M., and Holborow, E. J. (1961). Brit. med. F., 2, 909.

Hill, O. W. (1961). Ibid., 1, 1793.

Hill, O. W. (1961). Ibid., 1, 1793. Weir, D. M., and Johnson, G. D. (1957). Ibid., 2, 732.

Holborow, E. J., Weir, D. M., and Johnson, G. D. (1957). Ibid., 2, 732. Carmichael, D. S. (1963). Ibid., 1, 656.
C. I

Lane, J. J., and Decker, J. L. (1960). F. Amer. med. Ass., 173, 982.

Mackay, I. R., and Gajdusek, D. C. (1958). Arch. intern. Med., 101, 30 Mackay, I. R., I., and Cowling, D. C. (1956). Lancet, 2, 1323.

- and Wood, I. J. (1962). Quart. F. Med., 31, 485.

Marshall, D. Eveland, W. C., and Smith, C. W. (1958). Proc. Soc. exp. Biol. (N.Y.), 98, 898.

Read, A. E., Sherlock, S., and Harrison, C. V. (1963). Gut, 4, 378.

Read, A. E., Sherlock, S., and Harrison, C.

Silva, H. (1963). Communication at the Renal Association, April, 1963. London.

Singer, J. M., Peralta, F. M., Lyons, H. D., and Plotz, C. M. (1961). Arthr. and Rheum., $4,124$.

Skanse, B., and Nilsson, S. B. (1961). Acta med. scand., 170, 599.

Weir, D. M., Holborow, E. J., and Johnson, G. D. (1961). Brit. med. F., 1, 933 . Holborow, E. J. (1962). Ann. rheum. Dis., 21, 40.

\title{
Heroin Addicts in a Casualty Department
}

\author{
A. J. CAMERON,* M.B., M.R.C.P.
}

During 1962 at least 30 heroin (diacetylmorphine) addicts were seen, 20 by the author personally, in a casualty department in central London. Nearly all these addicts volunteered the information that they took the drug, and injection marks were usually obvious. Hence it is thought that few addicts were missed among the patients attending the department. The number of known pethidine or morphine addicts seen here was much smaller.

Of the 30 addicts, 23 were men and seven women. Fifteen were known to be British, 12 were immigrants from Canada, and one came from the U.S.A. They were aged 19 to 46, with an average age of 29 years. The duration of addiction (as stated by the patient) was recorded in 20 cases. It ranged from six months to 18 years. Twelve British subjects had been addicted for an average of 6.7 years, whereas the

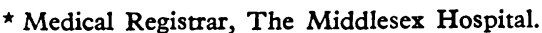

average duration of addiction in eight from across the Atlantic was 10.2 years.

\section{Drugs Taken}

All these patients were addicted to heroin, and most of them also took cocaine. The dose taken by any one addict varied from time to time. Possibly some exaggerated the amount they were taking in an attempt to get as large a supply as possible from the casualty officer. This was not usual, however, and where possible confirmation of the patient's story was obtained from his own doctor or a local chemist by telephone. The total amount of heroin taken in 24 hours (in four or more divided doses) was between $1 \frac{1}{4}$ gr. $(75 \mathrm{mg}$.) and $13 \mathrm{gr}$. (780 mg.), averaging over $5 \mathrm{gr}$. (300 mg.). Out of 23 patients whose records are complete 21 took cocaine as well as heroin, usually in equal quantities. 
It was noted that 25 patients were obtaining regular prescriptions from a doctor for their drugs and only two obtained all their supplies from black-market sources.

Many addicts regularly took large quantities of barbiturate. During the year under review six addicts were treated for overdoses of barbiturate. One said he "wanted to end it all." Others took large but non-lethal doses when short of heroin to minimize the discomfort of withdrawal symptoms until more heroin could be obtained. Addicts acquire some tolerance to barbiturates. Barbiturate anaesthetics such as thiopentone, it was noted, had to be given in larger doses to addicts than to normal persons.

\section{Attempts to Obtain Drugs}

An attempt to obtain drugs was the commonest reason for the addict's visit, and he often came during the night. Sometimes two addicts came together, apparently to give each other moral support in what might well be a difficult interview with the doctor.

They offered a variety of explanations to account for their need. Some claimed that their supply had been stolen or spilt, or that their own doctor was unexpectedly not available to provide a prescription. Some stories proved to be true, some not. It must be remembered that the heroin addict suffers marked physical discomfort if deprived of the drug for over eight to 14 hours (Isbell, 1963). Unfortunately, some addicts will sell any surplus that they are able to obtain. Most of those seen were unemployed, and their income from such sources as National Insurance was very small. Heroin and cocaine change hands in London at a price of 20s. to 30s. per gr. (60 mg.). (This information is based on personal questioning of addicts.)

Many addicts have an improvident nature. For example, two came to the casualty department on several occasions seeking drugs to ease withdrawal symptoms on Sundays. They obtained their supply daily from a chemist's shop on a doctor's prescription except that on Saturdays they collected enough for two days. Then instead of keeping some for Sunday they would squander all they had on the Saturday. Another addict used up a three-day prescription in one day because he was upset by the death of a friend.

One addict told a casualty officer that his own doctor was away (this later proved to be true). He claimed that as a result he was unable to obtain drugs for the next two days. He was therefore given, by a casualty officer, a prescription for $12 \mathrm{gr}$. each of heroin and cocaine to take to a local chemist. This addict had in fact a prescription covering the same two days from his own doctor. Charged by the police, he was given a conditional discharge by the magistrate, but later in the year was sent to prison for forging a prescription. The casualty officer, who had acted in good faith, was asked to give a statement but did not have to appear in court.

\section{Offences Against the Law}

Local and national newspapers were searched for information. At least 10 of these 30 addicts have been convicted since January 1962. One was imprisoned for a month for assault. Four had forged prescriptions for dangerous drugs. One had illegally in his possession $187 \mathrm{gr}$. of morphine. One addict broke into a chemist's shop and another into his own doctor's surgery, in the hope of finding drugs. Two were found to be obtaining prescriptions from two doctors simultaneously.

\section{General Appearance}

A few addicts looked well and were tidy and well dressed, especially the minority who had employment. But most were thin, poorly dressed, and often dirty. Unlike alcoholics, these addicts exhibit no obvious abnormality of mood or mental ability when under the influence of their drugs. Their manner is often polite and persuasive and they are not normally aggressive, though they may be resentful if the drugs they seek are refused.

\section{Withdrawal Symptoms}

Some addicts were seen with signs of heroin withdrawal (cocaine withdrawal does not cause physical illness). Signs noted included obvious tiredness and weakness, tremor, sweating, running nose, watering eyes, and frequent yawning. Other signs that generally appear later and were not seen in the casualty department were "goose flesh," cramps, diarrhoea, vomiting, extreme restlessness, and dilatation of the pupils. One patient drew attention to his large pupils but had no other signs of withdrawal; it is possible that he had used atropine. Two or three addicts claimed to have diarrhoea, but this could not be confirmed.

\section{Methods of Injection}

The drugs were normally obtained from a dispensing chemist on prescription in solid form (heroin as $1 / 6 \mathrm{gr}$. (10 mg.) tablets) and dissolved in a few $\mathrm{ml}$. of water in a small glass tube. Some addicts (including one who died of endocarditis, see Case 1) tried to sterilize their needle by boiling it in water in a glass tube over the flame of a cigarette lighter. Others did not bother to do even this. Some owned a syringe ; a popular alternative was a glass pipette with a rubber teat. The narrow end of the pipette was wrapped around with cigarette paper and wedged into the butt of a Luer-fitting needle (Fig. 1).

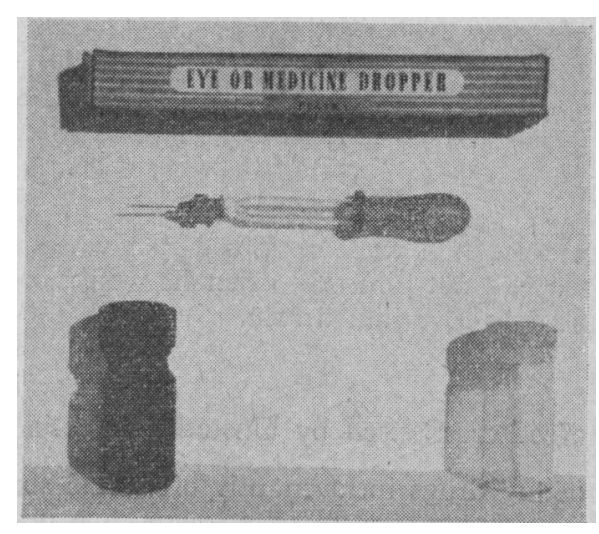

FIG. 1.-An addict's equipment.

Eighteen addicts took all their drugs (or "junk") intravenously-that is, they were "mainliners" to quote the slang term. The only woman in this group was given her injections by her husband, also an addict. Some used a belt as a venous tourniquet before injection. One used his shirt for this purpose, retiring regularly to a public lavatory to take it off. Three women and one man injected subcutaneously and two women used either route. Women have fewer suitable veins and perhaps use the needle less skilfully than men.

Addicts taking drugs intravenously had multiple puncture marks over the arm veins, which were often thrombosed. After years of injections, brown lines on the skin outline the veins with a permanently tattooed effect (Figs. 2 and 3 ). Addicts giving themselves subcutaneous injections had many puncture marks as well as scars due to previous abscesses on the thigh or buttock. In one case the scars were also on the upper arm. Injection marks were usually very obvious. Only in the addict 
with the shortest history (six months) could they have escaped notice on routine general physical examination.

\section{Wrist Scars}

Five out of 20 addicts seen by the author had healed scars on the flexor aspects of the wrists (Fig. 3). These were due to suicidal attempts, genuine or otherwise. One addict who had

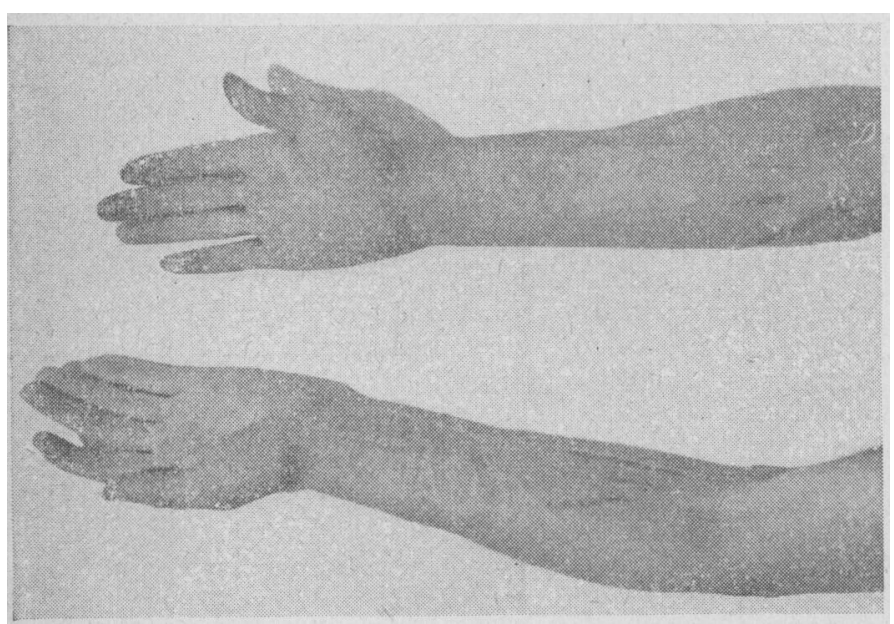

Fig. 2.-Tattooing over veins. Note also scars over front of wrists. ventricular hypertrophy and aortic stenosis. Next day he had a widespread petechial rash, signs of meningeal irritation, and diarrhoea. He died within 24 hours of coming to hospital. Necropsy showed aortic stenosis and bacterial endocarditis with multiple punctate haemorrhages in the brain. An infarct in the left temporal lobe explained his dysphasia.

Case 2.-A 25-year-old addict died from barbiturate poisoning. His case illustrates the need for caution when prescribing the large doses of drugs taken by these patients. He had in the past taken considerable amounts of barbiturate and of dexedrine. For about two years he had taken heroin and cocaine, but had been without these drugs for nearly four months while compulsorily detained in a mental hospital. He then absconded, but was arrested three days later for altering the quantities on a prescription. In the police station he demanded drugs and was seen by the police surgeon. His past history was not then known and the patient denied ever having been in a hospital. His story of taking regularly $3 \mathrm{gr}$. each of heroin and cocaine a day was accepted as true. He was allowed to inject himself intravenously with $1 \mathrm{gr}$. of each drug, but then collapsed and stopped breathing temporarily, soon reviving with artificial respiration. When he was seen in the casualty department shortly afterwards he was unsteady on his feet. There were many recent injection marks over the arm veins. The skin was markedly flushed and he was scratching himself vigorously. Though he gave a misleading history, in retrospect it is clear that the collapse, apnoea, skin flushing, and itching were due to an overdose of heroin. He had lost his tolerance for the drug during the months in the mental hospital. He was returned to the police station and was given no more heroin or cocaine. Seen to be well four hours later, he was found dead 30 minutes after that. Necropsy showed the cause of death to be barbiturate poisoning (blood barbiturate level

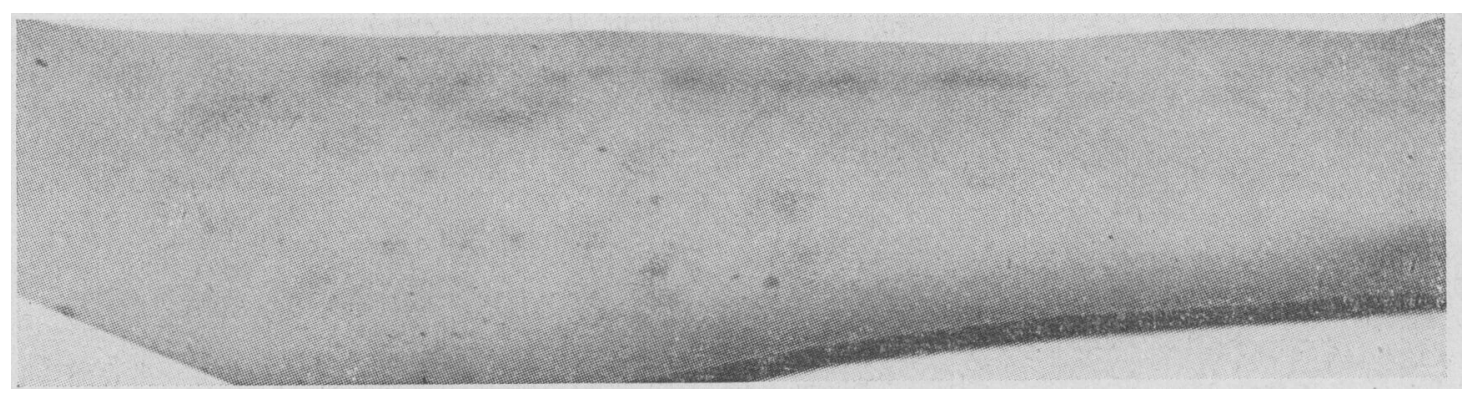

FIG. 3.-Scars and tattooing over arm veins.

some 30 scars on each wrist explained that when arrested (in Canada) he would cut himself so that he would be taken to a doctor who might give him heroin.

\section{Infections Caused by Unsterile Injections}

Addicts taking drugs intravenously often had some redness, slight swelling, and tenderness over veins, but none required active treatment for these infections. On the other hand, five of the six addicts injecting drugs subcutaneously had abscesses. Three women had abscesses of 10 to $15 \mathrm{~cm}$. diameter on the thigh or buttock that were incised under general anaesthesia. One woman with recurrent abscesses had seven broken needles buried in the soft tissue of her thighs. These were visible on the radiograph.

\section{Deaths Due to Addiction}

There were three deaths.

Case 1.-One patient died of bacterial endocarditis, the infection being almost certainly the result of unsterile intravenous injections. He was a man aged 24 who was found in a confused state in a public lavatory. He was thin, dirty, repetitively shouting monosyllabics, and inaccessible to reason. His body temperature was $101^{\circ} \mathrm{F}$. $\left(38.3^{\circ}\right.$ C.). Numerous injection marks were noted over the arm veins, some of which were thrombosed. There was a $6 \times 15 \mathrm{~cm}$. raised red area over the right antecubital fossa. His blood pressure was $90 / 50$ and there were clinical signs of left
$6.4 \mathrm{mg} . / 100 \mathrm{ml}$.$) . The partly digested capsules found in the$ stomach suggested that they had been taken about 20 minutes before death. He had concealed the barbiturate in his cell despite being searched by the police.

Case 3.-A third death was that of a man aged 21 (he is not included in the 30 addicts in this series) who shared a room in lodgings with one of these addicts, a Canadian. While the addict was asleep this man apparently injected himself with the addict's drugs which had been left lying about. Next morning he was found comatose but still breathing. Medical assistance was not sought. The morning after that he was found dead. At necropsy the cause of death was shown to be bronchopneumonia secondary to narcotic poisoning. There were only a few recent injection marks over the arm veins. Large amounts of heroin and cocaine were found in the body. Exactly how much he had taken was unknown, but it proved to be a lethal dose in a person who had presumably not acquired full tolerance to these drugs. Death from an overdose of heroin is very unlikely in addicts who have acquired such tolerance (Kolb, 1962, p. 118).

\section{Admissions to Hospital for Drug Withdrawal}

During 1962 five of these 30 addicts were transferred elsewhere from this casualty department for attempted drug withdrawal. When an addict expressed a desire to have such treatment he was usually admitted to a mental hospital on the same day. Where there was a reasonable chance of cure, as in the case of a 19-year-old girl, the addict was strongly urged to have treatment. Three patients had apparently never been 
admitted for drug withdrawal, but these addicts had clearly no desire to cure their habit.

The likelihood of cure in long-standing addictions is small. Eighteen of these addicts were known to have been in hospital, some on several occasions, for drug withdrawal but had relapsed. One said he had had 14 admissions and wanted no more "cold turkey"- the slang term for sudden withdrawal, so named because abruptly stopping heroin causes "goose flesh." Another patient said that when off drugs he was "a hopeless alcoholic" and "useless to my family." Only one of the present series was still managing without drugs six months after leaving hospital. At least six of the others admitted to hospital for withdrawal treatment during 1962 had relapsed before the end of that year.

\section{Discussion}

\section{Incidence}

The number of known heroin addicts (many of whom also used other drugs such as cocaine) in the United Kingdom was 68 in 1959, 94 in 1960, 132 in 1961, and 175 in 1962 (Reports to the United Nations, 1959-62). This contrasts with the number of narcotic addicts (most of whom took heroin) in the U.S.A.: there were 44,906 in 1960 (Traffic in Opium and Other Dangerous Drugs, U.S. Government Report, 1960). Nearly half the present series of addicts were Canadians. Some said they came here to seek a cure, but more seemed to be attracted by the relative ease with which drugs could be obtained and the lighter penalties for drug offences. Eight had come to Britain less than six months before they were first seen in the casualty department. Of these, one died, three were deported, and four returned voluntarily to Canada. With the coming into force of the Commonwealth Immigration Act in July 1962 the number of Canadian addicts arriving here has fallen. So the progressive rise in the number of heroin addicts in Britain cannot be fully explained by the temporary residence of Canadian drug-takers. There has been an increase in native addiction.

\section{The Law and the Addict}

It is an offence, except for qualified medical practitioners, pharmacists, and certain other exempted persons, to be in possession of substances listed in the Dangerous Drugs Acts unless obtained on a lawful prescription. It is also an offence for a person receiving treatment from one doctor to obtain a supply of dangerous drugs from a second doctor without disclosing that he is being supplied by the first doctor (Drug Addiction: Report of the Interdepartmental Committee, 1961). A qualified medical practitioner may only give prescriptions for dangerous drugs when they are required for purposes of medical treatment. The Rolleston Committee (1926), whose recommendations were incorporated in the Dangerous Drugs Act, defined "circumstances in which morphia or heroin may be legitimately administered to addicts." These included " persons for whom, after every effort has been made for the cure of addiction, the drug cannot be completely withdrawn either because: (1) complete withdrawal produces serious symptoms which cannot be satisfactorily treated under the ordinary conditions of private practice, or (2) the patient, while capable of leading a useful and fairly normal life so long as he takes a certain non-progressive quantity, usually small, of the drug of addiction, ceases to be able to do so when the regular allowance is withdrawn."

A casualty officer is clearly acting within the law in giving a prescription for heroin to an addict suffering withdrawal symptoms. And a general practitioner who gives regular prescriptions to an addict who has relapsed after being treated for his addiction as an in-patient, perhaps on several occasions, is justified if the patient can lead a reasonably normal life only with the aid of drugs. The Interdepartmental Committee (1961) strongly recommended that a doctor, before embarking on prescribing a dangerous drug for a lengthy period (say in excess of three months) should obtain a second opinion in writing. It is also advisable for him to notify the Home Office to check that the addict is not already receiving prescriptions from another doctor (Hobson, 1956). Some doctors (and many addicts) are under the impression that the Home Office maintains an official register of addicts, but this is not the case. The Interdepartmental Committee (1961) were, however, of the opinion that " nearly all addicts are known to the Home Office, the Ministry of Health and to the Department of Health for Scotland."

\section{Position in U.S.A.}

The incidence of narcotic addiction in the U.S.A. is much greater than in Britain. American laws relating to drugs differ fundamentally from our own in that the doctor is not allowed to prescribe narcotics in the long-term management of addiction (Cameron, 1963) and many American doctors have in the past been imprisoned for doing so (Kolb, 1962, p. 146). In Britain addicts convicted for obtaining drugs illegally have been put on probation or sentenced to a few months' imprisonment. In the U.S.A., under the Narcotic Control Act of 1956, a first conviction for possessing drugs carries a minimum sentence of two years (with the possibility of parole) and for a third such offence the minimum sentence is 10 years (with no parole) and the maximum 40 years (Kolb, 1962, p. 149). Heavy penalties have not solved the problem of addiction in America, as some 45,000 addicts apparently continue to obtain illegally enough drugs to provide for several daily injections each.

\section{Trading in Drugs}

There is considerable temptation for the impecunious addict to sell drugs to other addicts or to potential addicts. This type of illegal transaction is known to occur, but is not easily detected by the police (Lyle, 1953). The danger of overprescribing by doctors must therefore be emphasized. An addict who is obtaining prescriptions for $10 \mathrm{gr}$. (600 mg.) each of heroin and cocaine daily can often satisfy his own craving on half this amount and may then sell the remainder. The larger the quantity of drugs available on the black market, the more new cases of addiction are likely to occur.

\section{Aspects of Management}

Some time should be spent with each patient urging him to accept treatment. Immediate admission to a suitable psychiatric unit is the ideal arrangement. Failing this the addict may be persuaded to attend a psychiatric clinic in the first instance, though it must be borne in mind that many will fail to keep their appointments.

Attempts to wean the heroin addict off his drug without admission to hospital are most unlikely to succeed and are not recommended (Report of the Interdepartmental Committee, 1961). The methods of drug withdrawal used are outside the scope of the present article. One eminent American authority (Isbell, 1963) states that at least 15 to $20 \%$ of addicts remain abstinent for five years after one adequate period of treatment.

Many addicts cannot be cured. They present a social and medical problem. Untidy, unkempt, and unreliable, requiring a prescripition every few days, they are difficult to manage, and many doctors are understandably reluctant to treat such patients. Addicts will go to almost any lengths to obtain drugs -from illegal sources if none other proves fruitful. The doctor 
who takes on responsibility for the long-term care of an addict is, in the author's opinion, performing a public service in keeping his patient out of trouble. Mention has already been made of the desirability of obtaining a second opinion on the case and of informing the Home Office.

The story given by the addict who comes to a casualty department asking for drugs cannot be accepted unreservedly and whenever possible must be checked-for example, by a telephone call to the addict's own doctor or to local dispensing chemists. It is suggested that drugs should only be given to addicts showing signs of withdrawal. Others who claim that their supply has run out but are not suffering as a result can be told to report back later if necessary. The addict who is trying to obtain extra drugs, perhaps for re-sale, is unlikely to come back with signs of withdrawal. It may be justifiable and indeed a necessary act of kindness occasionally (for instance at night) to give a suffering addict a dose of heroin, which he should inject himself before leaving the hospital. If he seems in need of a larger supply, say in the event of his own doctor being ill, it is suggested that he be given a prescription to take to a chemist rather than to the hospital dispensary. The official system of checking Dangerous Drug prescriptions can thus more easily detect addicts who are illegally obtaining supplies from two doctors simultaneously. If an addict is supplied with drugs by the hospital his own doctor should later be informed.

Addicts admitted to hospital for reasons other than attempted cure of their craving should be allowed their normal amounts of drugs while in the ward. Otherwise they will discharge themselves even though urgently needing treatment for serious or painful conditions.

\section{Summary}

In one year, 30 heroin (diacetylmorphine) addicts, most of whom also took cocaine, were seen in a casualty department in London. Most were obtaining regular supplies of drugs legally on prescription.
Addicts often came to the hospital seeking supplies of drugs. They also came for treatment of infections due to unsterile injections; one died from bacterial endocarditis. Six addicts presented with barbiturate poisoning.

The physical features of heroin addicts are described. They are easily identified by the scars of multiple injections.

Some addicts were transferred elsewhere for in-patient withdrawal treatment, but the relapse rate was high.

The problem of heroin addiction in Britain is discussed. There has been a recent increase in the relatively small number here that could not be explained by an influx of Canadian addicts, many of whom soon returned home.

The legal position of the doctor treating the addict is outlined, and compared with the situation in the U.S.A.

Some suggestions on the management of addicts are made.

I wish to thank H.M. Coroner for St. Pancras and H.M. Coroner for West London for permission to inspect reports of inquests. I am grateful to Dr. M. P. Spence for help in writing this paper.

\section{REFERENCES}

Cameron, D. C. (1963). Amer. f. Psychiat., 119, 793.

Drug Addiction: Report of the Interdepartmental Committee (1961). H.M.S.O., London.

Hobson, J. A. (1956). Brit. F. Addict., 53, 48.

Isbell, H. (1963). In Textbook of Medicine (Cecil-Loeb), edited by P. B. Beeson and W. McDermott, p. 1748. Saunders, London.

Kolb, L. (1962). Drug Addiction. Charles C. Thomas, Springfield, Ill.

Lyle, G. (1953). Brit. F. Addict., 50, 47.

Public Health Reports (U.S.) (1963). 78, 669.

Reports to the United Nations by Her Majesty's Government in the United Kingdom of Great Britain and Northern Ireland on the Working of the International Treaties on Narcotic Drugs (19591962). Home Office, London.

Rolleston Committee: Report of the Departmental Committee on Morphine and Heroin Addiction (1926). H.M.S.O., London.

Traffic in Opium and Other Dangerous Drugs: Report by the Government of the U.S.A. for the Year Ending December 31, 1960.

\title{
Pernicious Anaemia, Myxoedema, and Hypogammaglobulinaemia - A Family Study
}

\author{
F. I. LEE,* M.B., M.R.c.P. ; G. C. JENKINS, † PH.D., M.B., B.S. ; D. T. D. HUGHES, $\ddagger$ M.A., B.SC., B.M., M.R.C.P. \\ G. KAZANTZIS,§ PH.D., M.B., F.R.C.S., M.R.C.P.
}

Brit. med.F., 1964, 1, 598-602

Early in the history of pernicious anaemia it was recognized that the condition occurred occasionally in members of the same family (Sinkler and Eschner, 1896). The suggestion was made that there may be genetically determined factors in the aetiology of the disease. Many additional families (Gulland, 1907 ; Bartlett, 1913 ; Hurst, 1927) were reported and some largescale surveys have revealed an increased incidence of pernicious anaemia in relatives of affected patients. Different workers have reported incidence varying from $5 \%$ (Levine and Ladd, 1921), $8 \%$ (Stamos, 1940) to $18 \%$ (Castle and Minot, 1936).

* Senior Medical Registrar, the London Hospital

+ Senior Registrar, Department of Clinical Pathology, the London Hospital. (Present post: Consultant Haematologist, North Middlesex Hospital, London.)

$\ddagger$ Medical Registrar, the London Hospital.
S Department for Research in Industrial Medicine, Medical Research Council.
There appears to be a particularly high family incidence in those rare cases where the condition occurs in children and young adults (Reisner, Wolff, McKay, and Doyle, 1951; Mollin, Baker, and Doniach, 1955 ; Leikin, 1960 ; Lambert, Prankerd, and Smellie, 1961).

The present study is of a family (see Fig. 1) in whom the mother and daughter have pernicious anaemia. The mother also has myxoedema and the daughter has hypogammaglobulinaemia. In addition, the mother's sister has no absorption of vitamin $\mathrm{B}_{12}$, demonstrated by a Schilling (1953) test, and hypergammaglobulinaemia.

\section{Case 1}

The patient was a housewife aged 56. In 1936, when aged 31, she attended the London Hospital complaining of having had faints, 